\title{
REGIONAL DEVELOPMENTS
}

At the regional and country level, developments in 2017 had important repercussions for food security and nutrition. This section offers perspectives on food policy developments across the major regions: Africa, the Middle East and North Africa, Central Asia, South Asia, East and Southeast Asia, and Latin America and the Caribbean. Globalization and the impact of growing antiglobalization pressures on food security are examined for each region, along with many other current topics:

- Africa's need to raise investment in agriculture and build resilience, especially given continued threats from climate variability and conflict

- Substantial reforms undertaken in the Middle East and North Africa, marked by stark differences between those countries directly affected by conflict and those not affected

- Notable steps taken toward regional integration in Central Asia, opening new doors for cooperation

- Global food value chains creating new opportunities in South Asia

- Investments in agricultural transformation, regional connectivity, and e-commerce in East and Southeast Asia

- Benefits of economic recovery in Latin America and the Caribbean threatened by lingering impacts of economic slowdown and changing US policies 
AFRICA

MIDDLE EAST AND NORTH AFRICA

CENTRAL ASIA

SOUTH ASIA

EAST AND SOUTHEAST ASIA

LATIN AMERICA AND THE CARIBBEAN
74

78 |

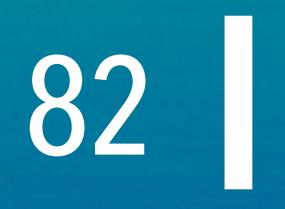

86

901

94 


\section{Africa}

\section{Call for Sustaining Growth and Building Resilience}

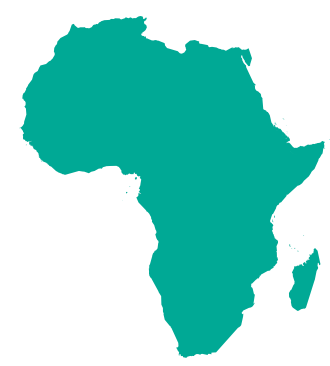

\section{TSITSI MAKOMBE, JULIA COLLINS, JOHN ULIMWENGU, AND OUSMANE BADIANE}

Tsitsi Makombe is a senior program manager, Julia Collins is a research analyst, and John Ulimwengu is a senior research fellow, West and Central Africa Office, and Ousmane Badiane is director for Africa, International Food Policy Research Institute, Washington, DC, USA.

Africa's sustained economic growth since the early 2000 s has been underpinned, in part, by globalization through increased investments, including capital inflows, and by favorable commodity prices that enabled strong export growth. The improved growth performance resulted in declines in poverty, hunger, and malnutrition and enabled a middle class to flourish. However, Africa south of the Sahara still has a higher poverty rate and number of poor compared to the other regions of the world. Furthermore, the continent's dependence on exports of primary commodities leaves it vulnerable to volatile global markets, as witnessed in 2016 when the sharp decline in commodity prices slowed economic growth. Meanwhile, conflicts and increased climate variability continue to threaten food security and nutrition in Africa. In addition, high poverty levels and conflict have forced many Africans to migrate abroad illegally, especially to Europe, under treacherous conditions.

In the face of the headwinds of antiglobalism, African countries should focus on implementing broad-based policy reforms that will allow their economies to thrive in a competitive global environment, generate employment, and build resilient food systems and livelihoods. Policy reforms should also promote trade openness, export diversification, and foreign direct investment (FDI) to keep these countries on a path of sustained and inclusive growth and food security.

\section{MAJOR POLICY DEVELOPMENTS IN 2017}

Gross domestic product (GDP) growth in Africa south of the Sahara was expected to have reached 2.6 percent in 2017, up from a sluggish 1.4 percent in
2016. Modestly stronger growth can be attributed to the rebound in oil and agricultural production; the easing of drought, which stressed southern Africa in 2016 and early 2017; and an improved global economic environment. ${ }^{1}$

Africa's agriculture sector continues to grow steadily. For Africa as a whole, agricultural value-added grew at 4.7 percent annually in 2008-2016, up from 4.2 percent in 2003-2008 but below the Comprehensive Africa Agriculture Development Programme (CAADP) target of 6 percent. Nonetheless, 13 countries surpassed the 6 percent target in 2008-2016.

Prior to the 2008-2009 global financial crisis, public agricultural expenditure for Africa as a whole had also increased steadily. Following the crisis, however, the rate of growth in expenditures decelerated, even turning negative (Table 1). For the region as a whole, the share of agricultural expenditures in total public expenditures continues to fall short of the CAADP target of 10 percent; only five countries managed to meet the target on average during the 2008-2016 period. Although the amount of annual agricultural expenditure has grown significantly during the CAADP period, the recent decreases in absolute expenditures represent a serious new development that requires prompt attention.

Rates of poverty, hunger, and child malnutrition declined over the last 20 years in Africa but remain relatively high. The proportion of Africa's population living in poverty and the prevalence of child underweight and stunting declined slightly between 20032008 and 2008-2016, but high levels persist (Figure 1). Some countries achieved more rapid improvement, with reductions in poverty of 50 percent or more 
between 2003 and 2016 in Chad, Mali, Morocco, Namibia, the Republic of the Congo, and Swaziland. Five countries (Algeria, Angola, Equatorial Guinea, Morocco, and Tunisia) saw reductions of 50 percent or more in the prevalence of underweight children between 2003 and 2016, while Angola and Tunisia saw similarly large reductions in child stunting. Hunger levels, as measured by the Global Hunger Index (GHI), are still considered "serious" or "alarming" in most African countries; the regional GHI score for Africa south of the Sahara is considered "serious." Several African countries saw significant gains, with Senegal showing the largest improvement (51 percent) in its $\mathrm{GHI}$ score between 2000 and 2017.

\section{INTERNATIONAL LINKAGES}

In the face of economic slowdown and a decline in export revenues, attracting FDI becomes critical to sustaining economic recovery. Overall, FDI flows to Africa decreased by 3 percent in 2016 to US $\$ 59$ billion. ${ }^{3}$ However, FDI levels vary greatly across the continent, with over half of total FDI directed to five countries (Angola, Egypt, Ethiopia, Ghana, and Nigeria). Egypt's increase of 17 percent in FDI reflects the discovery of gas reserves, while the 28 percent decline in the Democratic Republic of the Congo followed the sharp fall of global metals prices. In East Africa, FDI to Ethiopia increased by 46 percent, with rising investment in manufacturing and infrastructure. In West Africa, FDI grew by 12 percent, boosted by increased investment in oil and other natural resources in Nigeria and Ghana. FDI in southern Africa decreased by 18 percent, driven by oil-related declines in Angola.
Africa's FDI inflows are expected to reach about US $\$ 65$ billion in 2017, driven by moderately higher oil prices as well as non-oil investment. For 2017, investment promotion agencies rank agriculture, food and beverages, and utilities as the most promising industries for attracting FDI to Africa. ${ }^{4}$ Multinational enterprises from the United States, the United Kingdom, and France are still the leading investors in Africa; however, the biggest surge in FDI from 2010 to 2015 came from China, with an increase of 169 percent.

In terms of trade, African countries have yet to reverse the declines in exports and imports that started in 2012 and 2014, respectively. The declines are driven mostly by low commodity prices, more modest growth in China and other trading partners, and drought affecting parts of Africa. Overall, exports fell by 12 percent in 2016, with most of the decline concentrated in oil-producing countries that were affected by low oil prices. ${ }^{5}$

Conflict, drought and other natural disasters, and stubbornly high poverty have led to high rates of internal displacement and emigration. In response to the unprecedented wave of migration from Africa, the $\mathrm{G} 20$ finance ministers and central bank governors adopted the Compact with Africa in March 2017 to promote private investment as a means to address the underlying causes of migration. The initiative will establish investment compacts between individual African countries and partners, including development banks, international organizations, and donors. The compacts will outline government policy actions and technical and financial support from partners to improve the enabling environment for investors.

TABLE 1 Public agricultural expenditures (PAE) and nutrition outcomes in Africa

\begin{tabular}{|l|c|c|} 
& $2003-2008$ & $2008-2016$ \\
\hline PAE annual average growth & $11.0 \%$ & $-4.8 \%$ \\
\hline PAE as share of total public expenditures & $3.5 \%$ & $3.0 \%$ \\
\hline Poverty headcount ratio, \$1.90/day poverty line & $45.6 \%$ & $42.2 \%$ \\
\hline Prevalence of underweight in children under five & $22.4 \%$ & $19.8 \%$ \\
\hline Prevalence of stunting in children under five & $39.2 \%$ & $35.3 \%$ \\
\hline Global Hunger Index (GHI) score & 43.5 (value for 2000) & 29.4 (value for 2017) \\
\hline
\end{tabular}

Source: T. Makombe et al., "Tracking Key CAADP Indicators and Implementation Processes," in A Thriving Agricultural Sector in a Changing Climate: Meeting Malabo Declaration Goals through Climate-Smart Agriculture-ReSAKSS Annual Trends and Outlook Report 2016, ed. A. De Pinto and J. M. Ulimwengu (Washington, DC: IFPRI, 2017); K. von Grebmer et al., 2017 Global Hunger Index: The Inequalities of Hunger (Bonn, Washington, DC, and Dublin: Welthungerhilfe, IFPRI, and Concern Worldwide, 2017).

Note: $\mathrm{PAE}=$ public agricultural expenditures. Data refer to Africa as a whole. 
FIGURE 1 Annual average percentage change in selected indicators, 2003-2008 and 2008-2016

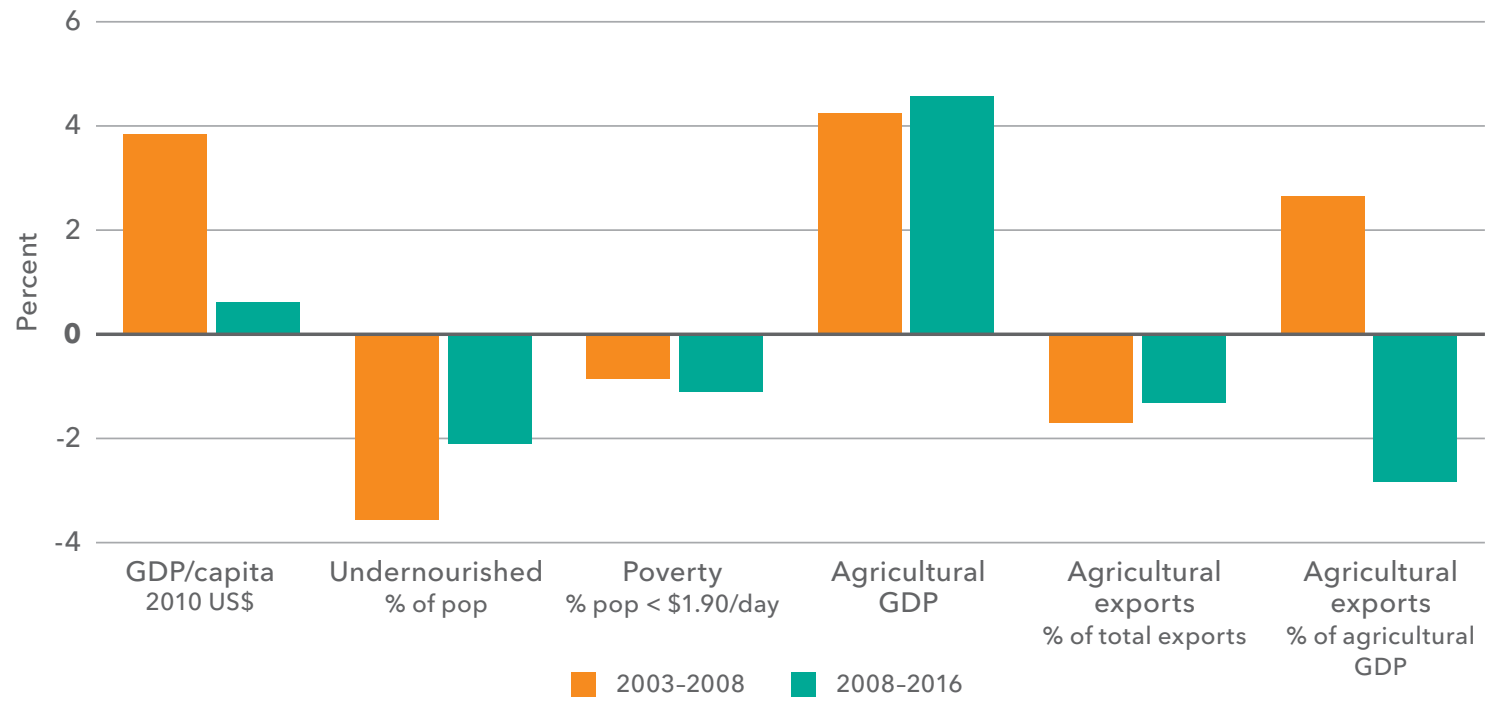

Source: A. De Pinto and J. Ulimwengu, ed., A Thriving Agricultural Sector in a Changing Climate: Meeting Malabo Declaration Goals through Climate-Smart Agriculture-ReSAKSS Annual Trends and Outlook Report 2016 (Washington, DC: IFPRI, 2017).

Note: Data refer to Africa as a whole. GDP = gross domestic product.

Seven African countries have already begun the process of developing investment compactsCôte d'Ivoire, Ethiopia, Ghana, Morocco, Rwanda, Senegal, and Tunisia.

During its presidency of the G20 in 2017, Germany proposed the establishment of a "Marshall Plan for Africa," in part to address causes of migration and create job opportunities for Africa's growing youth population. The plan represents a broad partnership between Europe and Africa under three pillars: economic activity, trade, and employment; peace, security, and stability; and democracy, rule of law, and human rights. ${ }^{6}$ As of January 2018, the final form of the plan was still taking shape.

\section{MALABO DECLARATION COMMITMENTS AND CAADP}

The year 2017 was pivotal in advancing the implementation of CAADP and the 2014 Malabo Declaration, which upheld key CAADP goals and committed to ambitious targets, including halving poverty, ending hunger, and reducing stunting to 10 percent and underweight to 5 percent by 2025. Under the Malabo Declaration commitment to "Mutual Accountability to Actions and Results," African leaders pledged to conduct a continentwide review every two years to track and report on progress. The inaugural biennial review report, including an innovative African Agricultural Transformation Scorecard, was launched during the January 2018 African Union Summit. According to the report, out of 47 reporting countries, 20 obtained an overall agricultural transformation score of at least 3.9 out of 10 , indicating that they are on track to achieve the Malabo commitments by 2025. ${ }^{7}$ During 2016 and 2017, countries, regions, continental institutions, and technical partners made concerted efforts to establish guidelines and collect, analyze, and report on data. The International Food Policy Research Institute (IFPRI), through the Regional Strategic Analysis and Knowledge Support System (ReSAKSS), assisted throughout, helping to design guidelines, develop indicators, and establish a roadmap for the biennial review process. ReSAKSS also provided training and technical assistance to countries and regional economic communities for data collection, analysis, and reporting, and assisted in drafting the continental report. A total of 47 of 55 African countries submitted their country reports in 2017. The draft continental report was presented to the African Union Commission Specialized Technical Committee in October 2017 in preparation for its submission to the African Union Assembly. 
Countries and regions also made significant progress in 2017 in formulating new national agriculture and food security investment plans. Many plans that had been implemented under the Maputo Declaration of 2003 came to a close in 2015, and countries began to develop next-generation plans under the 2014 Malabo Declaration, with coordination and assistance from the African Union Commission, the Planning and Coordinating Agency of the New Partnership for Africa's Development, regional economic communities, and technical partners including IFPRI and ReSAKSS. In 2016 and 2017, eight countries held events to launch the design process for the plans, and the Economic Community of West African States (ECOWAS) led an effort to support all 15 of its member states in completing their plans by the end of 2017. As of October, most ECOWAS countries had a draft document. IFPRI and ReSAKSS provided technical assistance to help guide the design of next-generation plans, including modeling expected growth and poverty outcomes of the draft plans.

\section{THREATS TO FOOD SECURITY}

Climate shocks and conflict severely threatened food security in a number of countries, with famine or near-famine conditions experienced in South Sudan, Nigeria, and Somalia in 2017. Continued poor rains in parts of Ethiopia, Kenya, and Somalia in late 2016 and early 2017 caused a major food security crisis, particularly in Somalia and Ethiopia. ${ }^{8}$ As of December 2017, emergency conditions were expected to continue in parts of the region into $2018 .^{9}$ The drought has significantly impacted agricultural and pastoral livelihoods in the Horn of Africa, and sustained humanitarian assistance will likely be needed.

In addition, civil unrest and conflict put millions at risk in Somalia and South Sudan. In Somalia, food crisis and emergency conditions are expected to continue through mid-2018..$^{10}$ In South Sudan, the government and the United Nations officially declared a famine in parts of the country in February 2017.11 Although the famine declaration was lifted in June, 6 million people-half the population of South Sudan-were estimated to be severely food insecure. ${ }^{12}$ With livelihoods as well as access to food aid still affected by conflict, food security crisis or emergency conditions were expected to persist in broad areas of the country well into $2018 .^{13}$
The Boko Haram insurgency continued in 2017 in northeastern Nigeria, where unrest, restrictions on trade, and displacement have resulted in crisis and emergency food security conditions and limited access to food aid. ${ }^{14}$ The Kamuina Nsapu insurgency in the Democratic Republic of the Congo displaced over a million people in 2016 and 2017. Although some refugees had been able to return as of October 2017, the country's food security crisis is projected to persist into $2018 .^{15}$

\section{AND BEYOND}

Moderately higher economic growth is expected for Africa in 2018, with GDP projected to grow at 3.2 percent. However, growth remains vulnerable to fiscal risks related to rising debt and debt-servicing costs, especially in natural resource-exporting countries. Growth also remains vulnerable in non-resource-intensive countries in the absence of a recovery in prices of commodities such as cocoa. ${ }^{16}$ To support stronger growth, African countries urgently need to reverse the decline in agricultural expenditure growth and raise investments to boost agricultural productivity. They need to continue the improvement of macroeconomic and sectoral policies that ended decades of economic decline and stagnation and ushered the continent into a prolonged period of growth and recovery. In particular, countries need to improve the management of debt, continue to pursue a more conducive business environment for the private sector, and attract FDI.

In addition, African countries need to promote more inclusive development programs and make agriculture programs more nutrition sensitive if the Malabo Declaration goals are to become a reality. In light of continued threats to food security from climate and conflict, building resilience of livelihoods and food systems is urgently needed. Efforts to enhance resilience should include strengthening social protection measures and building and enhancing early warning systems to trigger action as food security crises emerge. Sahelian countries have proven institutional arrangements for monitoring and responding to crises that can be replicated in other regions. ${ }^{17}$ Resilience to droughts and other climate shocks can be built through wider adoption of climate-smart agriculture, which supports climate change adaptation and mitigation while sustaining or raising agricultural productivity. ${ }^{18}$ 


\section{Middle East and North Africa}

\section{A Tale of Two MENAs}

\section{CLEMENS BREISINGER, FATMA ABDELAZIZ, AND NADIM KHOURI}

Clemens Breisinger is a senior research fellow and leader of the Egypt Strategy Support Program and Fatma Abdelaziz is a senior research assistant, Development Strategy and Governance Division, International Food Policy Research Institute, Cairo, Egypt. Nadim Khouri is an independent researcher supporting the Global Agriculture and Food Security Program and the Egypt Strategy Support Program.

As the most food import-dependent and the most important oil-exporting region in the world, the Middle East and North Africa (MENA) clearly benefits from functioning global commodity markets. ${ }^{1}$ However, as in other parts of the world, people in the region do not always perceive globalization as a positive driver of development. Discontent with the inequities sometimes exacerbated by globalization, especially with respect to income and food security, probably contributed to the revolutions that started in $2010 .^{2}$ In several countries, the uprisings turned into armed conflicts, making MENA the region with the greatest number of conflicts and refugees in the world. ${ }^{3}$

\section{CONFLICT AND COMMODITY PRICES}

In Iraq, Libya, Somalia, Sudan, Syria, Yemen, and in certain areas of neighboring countries, manmade disasters continue practically unabated. In addition to the harrowing toll in deaths and casualties, incomes (measured as per capita gross domestic product [GDP]) declined in most of the countries in conflict, and food security (measured as food affordability) continued to deteriorate in all countries over the last year (Table 1). In Syria, an estimated 6.9 million people were food insecure as of July 2017, even with the significant ongoing injection of food assistance that is sustaining about the same number of people. ${ }^{4}$ In Yemen, roughly 65 percent of Yemeni households, representing 17 million people, are now food insecure, and a quarter of a million people are affected by cholera, 60 percent of whom are under the age of $18 .^{5}$ More than 3.5 million people are facing severe levels of food insecurity in Sudan, where relatively good harvests in 2017 were not enough to compensate for the difficulty in accessing food resulting from poverty, internal conflict, and the influx of more than a quarter of a million refugees fleeing violence in South Sudan. ${ }^{6}$

Some MENA countries not in conflict are strongly affected by conflict in neighboring countries. The constant threat of spillover effects and concerns related to insecurity and instability continue to limit confidence and economic activity in the region as a whole. The shadow of conflict depresses businesses and investment inflows and hampers the tourism sector, which had been a vital source of revenue, especially for the oil-importing countries. ${ }^{7}$ All this contributes to low growth rates that are failing to address high unemployment and improve living standards. ${ }^{8}$ And while evidence on the impact of hosting refugees highlights both opportunities and challenges, it is clear that host countries with large refugee populations need significant support from the global community. ${ }^{9}$ An estimated 25 percent of Lebanon's population now constitutes refugees, principally from Syria and Palestine, and over 660,000 Syrian refugees are registered within Jordan's borders, causing huge strains on public finances in both Lebanon and Jordan. ${ }^{10}$ In Yemen, more than 3 million people are reported to be internally displaced, risking a major refugee outflow into neighboring countries. ${ }^{11}$

Global commodity prices also strongly influenced developments in MENA countries in 2017. While global food prices remained relatively stable, changes in international oil prices put a spotlight on the dichotomy between oil importers and oil exporters that has shaped MENA economies for decades. In 2017, oil production cuts led by the Organization of the Petroleum Exporting Countries (OPEC) caused a rise in oil prices, but not enough to completely erase the exporting countries' losses of the last two yearsincluding low or even negative GDP per capita growth 
TABLE 1 GDP, food affordability, and policy changes

\begin{tabular}{|c|c|c|c|c|c|c|}
\hline & \multirow[b]{3}{*}{$\begin{array}{l}\text { GDP per capita } \\
\text { annual } \% \text { change } \\
2015-2016, \text { or } \\
\text { latest two years }\end{array}$} & \multirow[b]{3}{*}{$\begin{array}{l}\text { Affordability of } \\
\text { food (index) }\end{array}$} & \multicolumn{4}{|c|}{ Policy changes ${ }^{c}(2016 / 2017)$} \\
\hline & & & \multicolumn{2}{|c|}{ - Policy reform in 2016} & \multicolumn{2}{|c|}{ - Policy reform in 2017} \\
\hline & & & $\begin{array}{l}\text { Macro/ } \\
\text { fiscal/ } \\
\text { trade }\end{array}$ & $\begin{array}{l}\text { Investment/ } \\
\text { investment } \\
\text { climate }\end{array}$ & $\begin{array}{c}\text { Social } \\
\text { protection }\end{array}$ & Agriculture \\
\hline \multicolumn{7}{|l|}{ Oil exporters } \\
\hline Algeria & 1.8 & -1.5 & $\bullet \bullet \bullet \bullet$ & $\bullet$ & & $\bullet$ \\
\hline Bahrain & 0.2 & -1.0 & $\bullet \bullet \bullet \bullet \bullet$ & & & \\
\hline Kuwait & -2.1 & -1.1 & $\bullet$ & & & \\
\hline Oman & -0.4 & -1.9 & $\bullet \bullet \bullet$ & & & \\
\hline Qatar & -1.3 & -0.3 & $\bullet \bullet$ & $\bullet$ & & \\
\hline Saudi Arabia & -0.5 & -0.7 & $\bullet \bullet \bullet \bullet \bullet \bullet$ & $\bullet$ & & $\bullet \bullet$ \\
\hline United Arab Emirates & 1.8 & -0.1 & $\bullet$ & $\bullet \bullet \bullet$ & & \\
\hline \multicolumn{7}{|c|}{ Oil exporters affected by conflict } \\
\hline Iraq & 7.8 & - & $\bullet \bullet$ & & $\bullet$ & \\
\hline Libya & - & - & & & $\bullet$ & \\
\hline Sudan & 2.2 & -1.9 & $\bullet \bullet$ & & & \\
\hline Yemen & -12.0 & -4.3 & & & & \\
\hline \multicolumn{7}{|l|}{ Oil importers } \\
\hline Comoros & -0.1 & - & $\bullet$ & & & \\
\hline Djibouti & 4.7 & - & $\bullet \bullet$ & & & $\bullet$ \\
\hline Egypt & 2.2 & -4.1 & $\bullet \bullet \bullet \bullet \bullet \bullet$ & $\bullet \bullet$ & $\bullet \bullet$ & \\
\hline Jordan & -1.2 & -1.1 & $\bullet \bullet \bullet$ & $\bullet \bullet$ & & $\bullet$ \\
\hline Lebanon & -0.9 & - & $\bullet$ & & $\bullet$ & \\
\hline Mauritania & -0.8 & - & & $\bullet$ & & \\
\hline Morocco & -0.3 & -1.5 & & $\bullet \bullet$ & $\bullet$ & \\
\hline Tunisia & 0.0 & -2.3 & $\bullet$ & $\bullet$ & $\bullet$ & \\
\hline West Bank and Gaza & 1.2 & - & & & & \\
\hline \multicolumn{7}{|c|}{ Oil importers affected by conflict } \\
\hline Syria & - & -4.2 & & & $\bullet$ & \\
\hline Somalia & - & & & & $\bullet$ & \\
\hline
\end{tabular}

Source: a World Bank, World Development Indicators Database, accessed September 2017; ${ }^{\mathrm{b}}$ Based on Economist Intelligence Unit Food Security Index; ' Policy changes in 2016 and 2017 based on authors' compilation from Economist Intelligence Unit, Country Reports (2016 and 2017).

Note: - indicates no data available. GDP = gross domestic product. Affordability includes the following indicators: Food consumption as a share of household expenditure, proportion of population under global poverty line, GDP per capita (US\$ PPP), agricultural import tariffs, presence of food safety net programs, access to financing for farmers.

and reduced food affordability-that were caused by a slippage in oil prices (Table 1). For oil-importing countries, the rise in oil prices in 2017 put more strain on private and public budgets, and inflation pressures increased substantially. ${ }^{12}$ The Comoros, Jordan, Lebanon, and Mauritania all experienced shrinking GDP per capita over recent years and a deterioration of access to food. GDP per capita growth in most other oil-importing countries that are not directly affected by large-scale conflict was too slow to lead to significant livelihood improvements for people and failed to improve access to food. In some cases, this may be explained by the short-term (often negative) impact of economic reforms initiated in recent years, and in other cases, by a reluctance to start critical reform processes or by the indirect impact of conflicts in neighboring countries or parts of their own territory-such as in Tunisia and Egypt, respectively. 


\section{ECONOMIC REFORMS}

Substantial reforms were undertaken in several oil-exporting countries as well as Egypt and Jordan in the area of macroeconomic policies and to a lesser extent in terms of investment climate, social protection, and agricultural policies. In response to low oil prices over the past years, the adjustment measures taken by oil-exporting countries include public-spending cuts; cuts in fuel and utilities subsidies in Kuwait (2016), Algeria and Bahrain (2017), and Saudi Arabia (planned 2018); and increases in excise taxes in Algeria and the Gulf Cooperation Council (GCC) states as well as a GCC-wide value-added tax scheduled for January $2018 .^{13}$ In the face of economic pressures, policy makers in other countries also pushed forward with reforms. These include the pass-through of recent exchange rate depreciations (Egypt, Sudan), implementation of a value-added tax (Egypt), and the removal of tax exemptions (Jordan). ${ }^{14}$ Despite persisting challenges, some countries kept up the momentum and continued the reform process in implementing energy subsidy reforms (Egypt, Sudan); undertaking structural reforms that improve the business climate and promote private sector activity; and easing key infrastructure bottlenecks (Egypt, Jordan, Mauritania).

While these policy reforms are expected to accelerate economic growth, create new jobs, and improve food security in the medium to long run, short-term negative impacts such as high inflation were observed in several countries. To protect the poor from the negative effects of reforms, several countries continued to expand existing social protection schemes addressing their nationwide social needs, including continuing to subsidize basic food items (Egypt, Lebanon, Morocco, Tunisia) and broadening cash transfer programs (Egypt). ${ }^{15}$

In addition, a few countries undertook some agricultural reforms, including expanding irrigated areas and improving the distribution of fertilizers and certified seeds (Algeria); enhancing water access to address severe food insecurity (Djibouti); and establishing a national strategy to facilitate the export of local agricultural products, especially fruits and vegetables, to the international market, with emphasis on the Gulf countries (Jordan). ${ }^{16}$ The Saudi government started rolling back its expansionary agricultural policy by terminating local production of wheat and is planning to phase out green fodder production by 2019, while continuing to encourage agricultural investments and production abroad for export back to its local market to meet strong domestic demand. ${ }^{17}$

\section{GOING FORWARD}

The MENA economies are united by their strong connections with the world, including through trade in goods and services (Figure 1). MENA will likely continue to rely increasingly on international trade for large components of its food supply; in view of this, the $G 20$ and other initiatives are facilitating the forecasting and exchange of information on potential difficulties in the production or trade of major crops. ${ }^{18}$ In addition, Gulf and other Arab countries have invested more than US\$9.3 billion in agricultural projects in Africa south of the Sahara, a trend that may have been encouraged by better governance and institutional frameworks in Africa. ${ }^{19}$ Oil exports will likely continue to shape the region for several years to come, despite the efforts of oil-exporting countries to diversify their economies. These facts should reassure the voices still clamoring for various degrees of protectionism in MENA countries.

Yet in 2017, the tale of two MENAs continued. One MENA was in conflict, the other MENA was managing as best it could, perhaps growing inured to the conflicts next door. In the present state of Arab crisis and disunity, it is difficult-but essentialto create a path to a more integrated economic outlook within MENA. The path toward integration can build on some progress made to date with the initial, fledgling steps toward a Pan-Arab Free Trade Agreement (PAFTA) by expanding into additional measures for intraregional integration: continued elimination of tariff and nontariff obstacles to trade; expansion of intraregional agreements and standards for services and investments, including telecommunications, transport, and financial services; harmonized employment regulations; and facilitation of labor movement. ${ }^{20}$

A major breakthrough could be made if countries not affected by conflict demonstrated that, by pursuing some of these reforms, Arab countries can achieve increases in GDP of 50 to 100 percent (as compared to the GDP that would be realized if they persisted with pre-2011 economic policies). ${ }^{21}$ Demonstrating this potential could offer 
FIGURE 1 Food imports and fuel exports in MENA compared to the world

\section{Food imports (\% of total imports)}

Countries in red = Countries affected by conflict

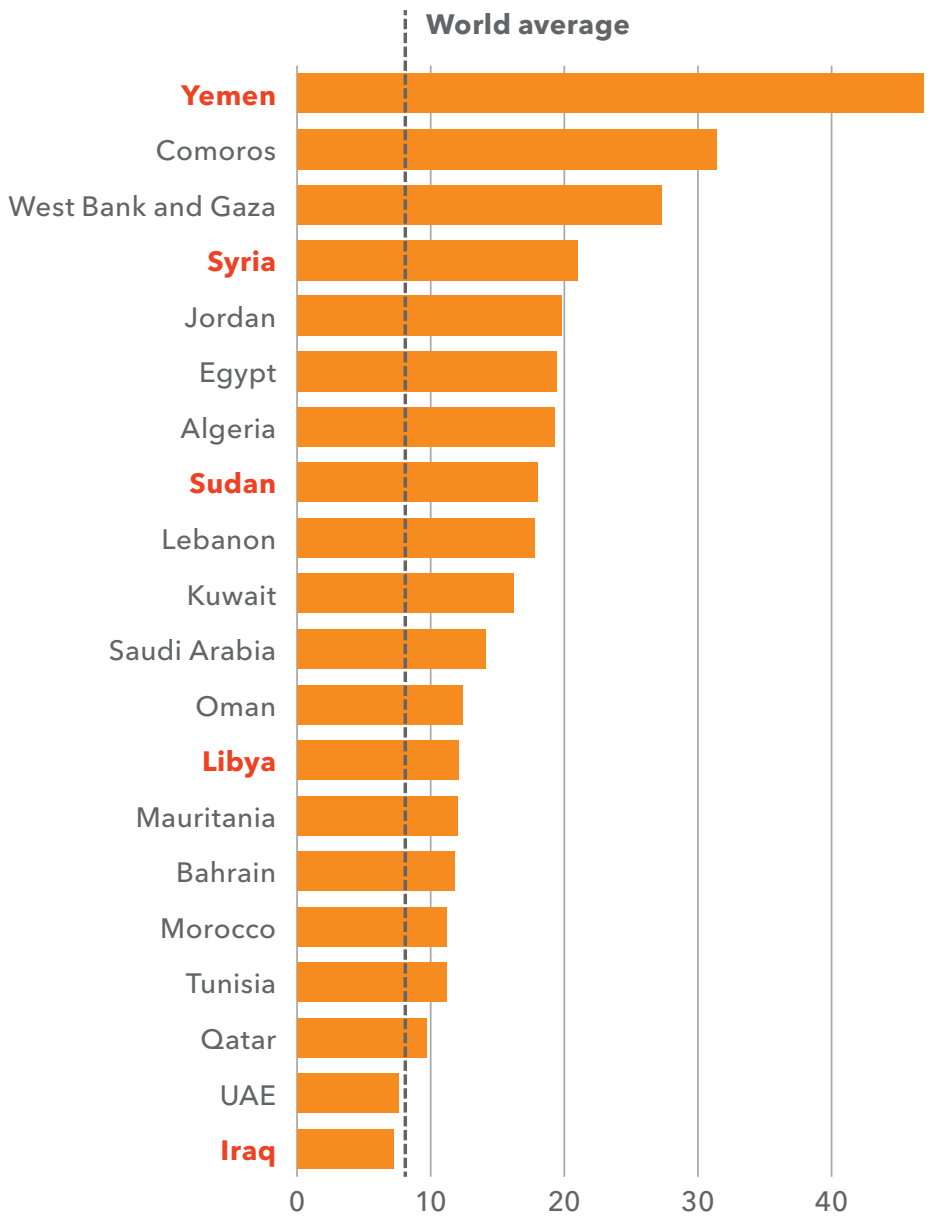

Fuel exports (\% of total exports)

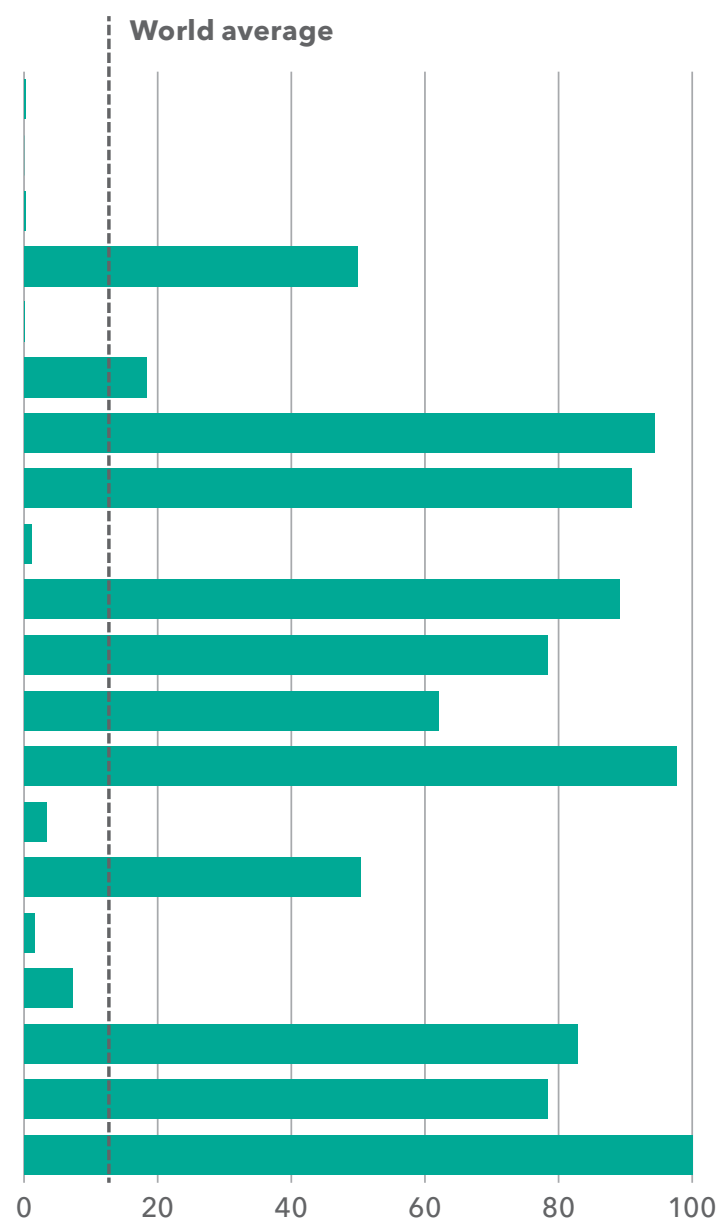

Source: Authors' compilation based on World Bank, World Development Indicators Database, accessed September 2017, https://data.worldbank.org.

Notes: Numbers reflect latest available data. "Fuel" includes mineral fuels, lubricants and related materials, including coal, coke and briquettes, petroleum, petroleum products and related materials, natural and manufactured gas, and electric current.

an alternative to the present state of conflict in the rest of the region and project a realistic hope for improvement. Achieving this change by 2025 will require immediate steps toward significant regional integration and country reforms toward more, not less, globalization. Globalization could become a positive driver of postconflict economic development and food security in MENA if the benefits of increased trade flows and investments are spread more widely and lead to greater prosperity for all.
While many MENA countries have missed opportunities for fundamental policy shifts in the past, now may be an opportune time for courageous, well-designed policy changes that go beyond macroeconomic reforms to allow all people to benefit from globalization. ${ }^{22}$ In view of the region's reliance on food imports, the food sector-and food security in particular-is an excellent place to start. 


\section{Central Asia}

\section{Steps toward Cooperation}

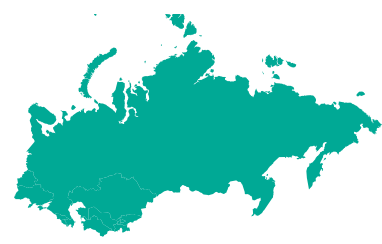

\section{KAMILJON AKRAMOV, JARILKASIN ILYASOV, AND ALLEN PARK}

Kamiljon Akramov is a research fellow, Jarilkasin Ilyasov is a research analyst, and Allen Park is a senior research analyst, Development Strategy and Governance Division, International Food Policy Research Institute, Washington, DC, USA.

After experiencing significant negative external shocks beginning in late 2014, the Central Asian countries-Kazakhstan, Kyrgyzstan, Tajikistan,

Turkmenistan, and Uzbekistan-began to enjoy more favorable external economic conditions in late 2016. Improvements include considerable increases in nonrenewable commodity prices and economic recovery in the region's key trading partners, including resumption of growth in Russia, a key driver of remittance flows and trade for Central Asian economies. 'These favorable external factors increase economic activity and food security in Central Asia through their impact on export earnings, remittance flows, and investments from the region's main economic partners.

The significant upturns in energy and metals prices supported economic recovery and appreciation of the Russian ruble in 2017, which in turn increased remittance flows to Kyrgyzstan, Tajikistan, and Uzbekistan (Figure 1). ${ }^{2}$ The combination of rebounding demand for migrant labor and a stronger ruble led to a 34 percent increase in remittance flows in nominal US dollar terms from Russia to Uzbekistan in the first half of 2017, compared to the same period in 2016. Remittance flows to Kyrgyzstan and Tajikistan increased by 28 percent and 22.4 percent, respectively, during the same period. Depreciation of the national currencies of Tajikistan and Uzbekistan led to even greater increases in remittances when accounted in the national currencies of these countries. For example, Tajikistan's somoni depreciated by almost 12 percent against the US dollar during the first three quarters of 2017.

Income from employment and remittances remain the primary drivers of poverty reduction and improved food security in the region. Increasing remittance inflows, while still well below 2012-2014 levels for Tajikistan and Uzbekistan, in combination with low inflation boosted the real purchasing power of households. Relatively stable food prices also contributed to the food security of poorer households. Thus poverty and undernourishment rates continued to decline. ${ }^{3}$ However, micronutrient deficienciesthat is, the lack of essential vitamins and minerals-remain common. In addition, overnourishment (overweight and obesity) is on the rise in all countries of the region. For instance, the overweight rate in Kyrgyzstan increased by more than 10 percentage points during the last decade and about 45 percent of adults were overweight in $2015 .^{4}$

\section{POLICY CHANGES IN THE REGION}

Since the change of political leadership in Uzbekistan following the death of its first president in 2016, the country has embarked on a set of important economic and governance reforms. To improve public administration, judicial systems, and social infrastructure, as well as to enhance economic growth and liberalize trade, the government adopted a Strategy of Actions on Further Development of Uzbekistan, including a five-point action plan for 2017-2021. ${ }^{5}$ Within the framework of this strategy to liberalize social and economic policy, the government adopted 15 laws and more than 700 normative legal and policy documents within the first nine months of 2017. The implementation of many of these policy changes will have important implications for food security and nutrition in the country.

Liberalization of the foreign exchange market could be considered the keystone of the new government's commitment to change. In September, President Shavkat Mirziyoyev signed a decree that allows citizens and businesses to freely exchange 
currency and supports an enabling environment for more sustainable and inclusive growth. ${ }^{6}$ Devaluation of the official exchange rate by almost 50 percent and unification of exchange rate markets are expected to stimulate exports and attract foreign investment. These reforms will also create a more favorable environment for Uzbekistan's agricultural producers, especially cotton and wheat producers, by eliminating the hidden tax on the sector created by exchange controls.

In the agriculture sector, the Uzbek government has continued to prioritize diversification and a shift from cotton production to horticultural products. Policy reforms aim to increase access to machinery, fertilizers, and credit, and simplify export requirements for local producers. ${ }^{7}$ However, it is not clear how this support will be provided, who will receive it, or whether such support will be fiscally sustainable. The government is also continuing its policy of increasing land allocation for horticultural crop production and allocating more land for forage and oil crops. ${ }^{8}$ Simultaneously, import tariffs and excise tax rates were substantially decreased or abolished for a number of important consumer goods and raw products. Increased availability of cheaper raw materials is expected to stimulate domestic production of final products and improve the country's competitiveness and export potential, as well as stabilize consumer prices in the domestic market. ${ }^{9}$

Infrastructure development is one of five areas prioritized by the new Uzbek strategy. In addition to ongoing development of roads and communications infrastructure, support for reconstruction of local bazaars and establishment of supermarkets and hypermarkets by the private sector is also being prioritized. Public support for the reconstruction of 301 major farm markets (dehkan bazaars) throughout the country between 2017 and 2019 aims to create jobs, modernize marketing infrastructure, and improve food safety standards.

Reforms for food safety and nutrition were also introduced, including fundamental changes in veterinary services. ${ }^{10}$ A new state Committee on Veterinary Services, formerly under the agriculture ministry, was established under the Cabinet of Ministers. The prime minister issued a resolution establishing a national Research Institute on Public Health and

\section{FIGURE 1 Total remittance inflows from Russia (2010-2017, quarters 1-3)}

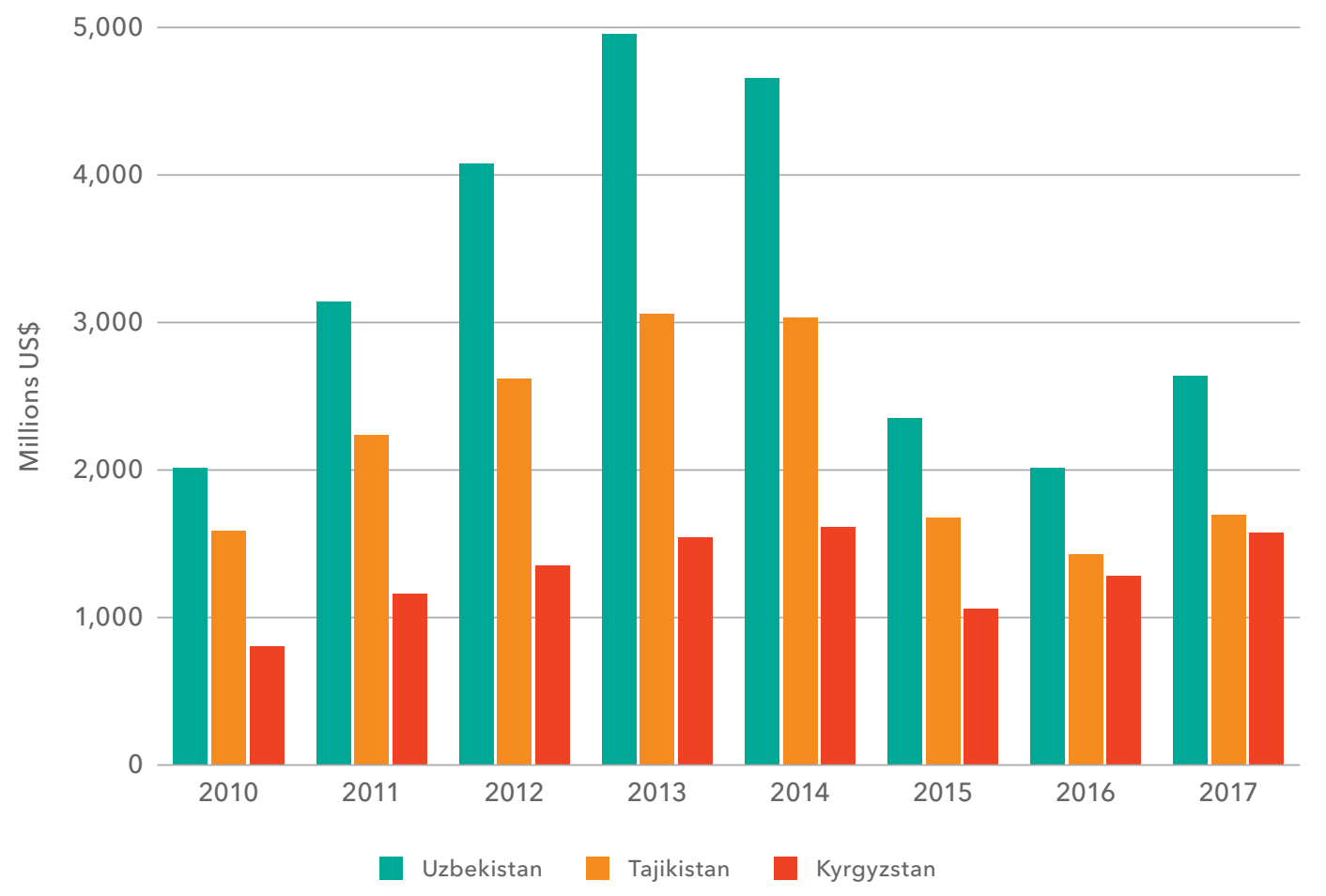

Source: Central Bank of Russia. 
Healthcare Administration, with responsibility for increasing public awareness regarding healthy lifestyles and nutrition, among other activities aimed at improving public health.

In 2017, Kazakhstan adopted an updated mid-term development strategy for 2050The Third Modernization of Kazakhstan: Global Competitiveness. ${ }^{11}$ It promotes the adoption of innovative and advanced technologies in the economy as well as sustainability and growth in prevailing major economic sectors, including agriculture, by investing in information and communications infrastructure, training, and education. The new strategy intends to promote labor productivity growth through technological modernization, creating an enabling business environment for entrepreneurship and market liberalization, and ensuring the rule of law and reducing corruption. ${ }^{12}$ The government approved a new State Program for Agro-Industrial Development (2017-2021) that prioritizes agricultural development through support for productivity growth, improved value chains, increased processing, and sustainable use of water and land resources. The program aims to shift public subsidies from grains to oil crops, expand state subsidies to smaller agricultural producers, and increase public funds for agricultural research and extension. The plan envisions stimulating agricultural exports by improving sanitary and phytosanitary compliance.

\section{REGIONAL INTEGRATION}

Poor regional integration and cooperation have been serious impediments to development and food security in Central Asia, but the recent political changes in Uzbekistan have created a more favorable environment for regional cooperation. ${ }^{13}$ The measures taken by the new Uzbek government have been welcomed by heads of state in the region and by major international development agencies. ${ }^{14}$

Relations are also thawing in the region more broadly. Diplomatic activity accelerated in 2017, following promising signs in 2016. This is a notable change for a region that has ranked poorly on almost all forms of regional integration, including trade, finance, infrastructure, migration, and institutional integration. ${ }^{15}$ It appears that Central Asian leaders are now beginning to pay serious attention to improving regional ties.
The recent initiatives were largely driven by the change in Uzbekistan. As the only country that borders all four other Central Asian countries, Uzbekistan has had running disputes with almost all of them over issues such as transport, energy, water, and trade. In 2017, the new Uzbek leadership initiated outreach to its neighbors and secured several commitments for further cooperation. For example, Turkmenistan and Uzbekistan, which had fraught ties for much of their post-independence histories, signed agreements to jointly develop energy deposits in the Caspian Sea and transmit electricity to other countries in the region.

Tajikistan and Uzbekistan resumed air flights after 25 years, reflecting a normalization of ties that had deteriorated largely due to disputes over water and energy resources. Uzbek president Mirziyoyev appeared to signal a softening of his country's opposition to hydropower projects in the region. Although no concrete agreement was signed between Tajikistan and Uzbekistan in this regard, the Uzbek government suggested that it was willing to compartmentalize the issue while pushing ahead with other areas of cooperation.

Furthermore, Uzbekistan and Kyrgyzstan achieved a breakthrough, agreeing to cooperate in the construction of the Kambarata Dam in Kyrgyzstan. As was the case with Tajikistan, Kyrgyzstan faced opposition over concerns about the dam's impact on the water supply to Uzbek farmers. Although specific terms for financial cooperation were not disclosed at a high-level meeting in September, the surprise agreement signaled a greater willingness among Central Asian countries to share resources. Uzbekistan and Kyrgyzstan also signed a landmark border demarcation treaty in 2017, settling a long-running dispute.

In addition, government representatives from Central Asia's two largest countries, Uzbekistan and Kazakhstan, met numerous times during the year, signing agreements for cooperation on agriculture, energy, industry, and transportation. Bilateral trade between Uzbekistan and Kazakhstan increased 35 percent through September as compared with the same period in 2016; Kazakh president Nursultan Nazarbayev spoke of setting a target of US $\$ 5$ billion in annual bilateral trade by 2020, a significant increase over the 2016 figure 
of US $\$ 2$ billion. Long-shuttered border crossings between the two countries were reopened, and a high-speed train link was launched between Almaty, Kazakhstan, and the Uzbek capital, Tashkent, in 2017.

While Uzbekistan's overtures to its neighbors drew the most attention, other countries in the region also continued to develop links. On the trade front, Kazakhstan and Kyrgyzstan agreed to increase railway cargo transport as part of their obligations under the Eurasian Economic Union. Moreover, Kazakhstan allocated US\$41 million in technical assistance to help Kyrgyzstan modernize its customs procedures and sanitary and phytosanitary testing facilities.

Regional integration was encouraged by initiatives from outside the region, such as China's continuing push to develop its Belt and Road Initiative. Several countries in the region, including Kazakhstan and Kyrgyzstan, already trade agricultural goods with China following a series of bilateral inspections and agreements. China and Kazakhstan agreed to further strengthen trade and cooperation in agriculture by signing a bilateral agreement in July 2017. The agreement includes the construction of a wheat terminal at the Kazakh-Chinese border and enhanced trade, investment, technology transfer, and innovation in agricultural production, wheat processing, and food safety infrastructure. Uzbekistan and China signed economic cooperation agreements worth US $\$ 20$ billion in May 2017 at the first meeting of the two countries' leaders. Chinese investment in logistics and infrastructure has increased in Central Asia in recent years, and several highway and railway projects crossing the region are being considered.

\section{LOOKING FORWARD}

Economic improvements in the region in 2017 primarily reflect recovery of commodity prices, macroeconomic stabilization, improved regional cooperation, and significant growth in remittance flows. Relatively positive price prospects for Central Asia's major commodity exports support a favorable economic outlook for the near future. Economic improvements in Russia and Kazakhstan will improve economic growth prospects, household welfare, and food security in other countries of the region through trade, investment, and remittances. In addition, greater regional cooperation and market integration in the context of ongoing reform efforts in Uzbekistan and other countries of the region may lead to a greater inflow of private investment. Also, China's Belt and Road Initiative may provide Central Asian countries new opportunities to address the region's infrastructure needs and strengthen regional economic connectivity.

On the downside, the Russian economy risks a slower recovery due to the expansion of Western sanctions in August 2017. ${ }^{16}$ Moreover, the benefits for economic growth and household welfare of higher export prices and remittance inflows will likely be partially offset by higher import prices, driven by higher energy prices and currency depreciation. Accelerating progress toward meeting Eurasian Economic Union standards for domestic production will remain a key challenge for Kyrgyzstan but will help Kyrgyz producers boost agricultural exports to the regional market. Continued challenges in the financial sector, especially in Tajikistan, may have negative impacts on the pace of poverty reduction and on food security as a result of reduced credit availability in pro-poor sectors of the economy and limited employment opportunities in low-skill sectors such as agriculture. ${ }^{17}$ 


\section{South Asia}

\section{Food Systems at a Crossroads}

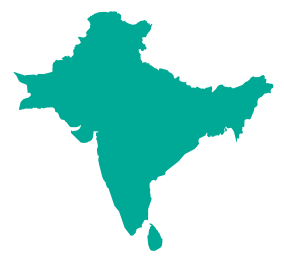

\section{ANJANI KUMAR, AKHTER AHMED, STEPHEN DAVIES, AND P. K. JOSHI}

Anjani Kumar is a research fellow, South Asia Office, International Food Policy Research Institute (IFPRI), New Delhi, India. Akhter Ahmed is a senior research fellow and chief of party, Bangladesh Policy Research and Strategy Support Program, IFPRI, Dhaka, Bangladesh. Stephen Davies is a senior research fellow, Development Strategy and Governance Division, IFPRI, Islamabad, Pakistan. P. K. Joshi is director for South Asia, South Asia Office, IFPRI, New Delhi.

Rising exports, low oil prices, higher infrastructure spending, and supportive macroeconomic policies helped to make South Asia the world's fastest growing region again in 2017, with economic growth projected to reach 7.1 percent in 2018. 'Growth across the region was not uniform, however, ranging from 0.6 percent in Nepal to 7.1 percent in both Bangladesh (a historical high) and India (Figure 1). ${ }^{2}$ Growth in agricultural gross domestic product (GDP) in South Asia also varied from country to country, shrinking by more than 4 percent in Sri Lanka in 2016, for example, and growing by 6 percent in Afghanistan. Agricultural GDP growth slowed in Bangladesh, but rose significantly in Bhutan and India.

\section{NATURAL CALAMITIES AND AGRICULTURAL GROWTH}

South Asia is highly vulnerable to the impacts of climate change. ${ }^{3}$ Climate variables such as temperature, rainfall, flooding, and drought increasingly affect agricultural activities in the region. Most South Asian countries weathered some form of natural calamity in 2017: by August, roughly a third of Nepal was flooded, affecting about 1.7 million people and damaging more than 34,000 homes ${ }^{4}$; heavy floods in Bangladesh damaged crops, including the country's main food staple, rice ${ }^{5}$; flooding and drought at turns plagued Sri Lanka as well as some 18 states in India,

FIGURE 1 Growth rates in GDP and agricultural GDP in South Asia, 2016

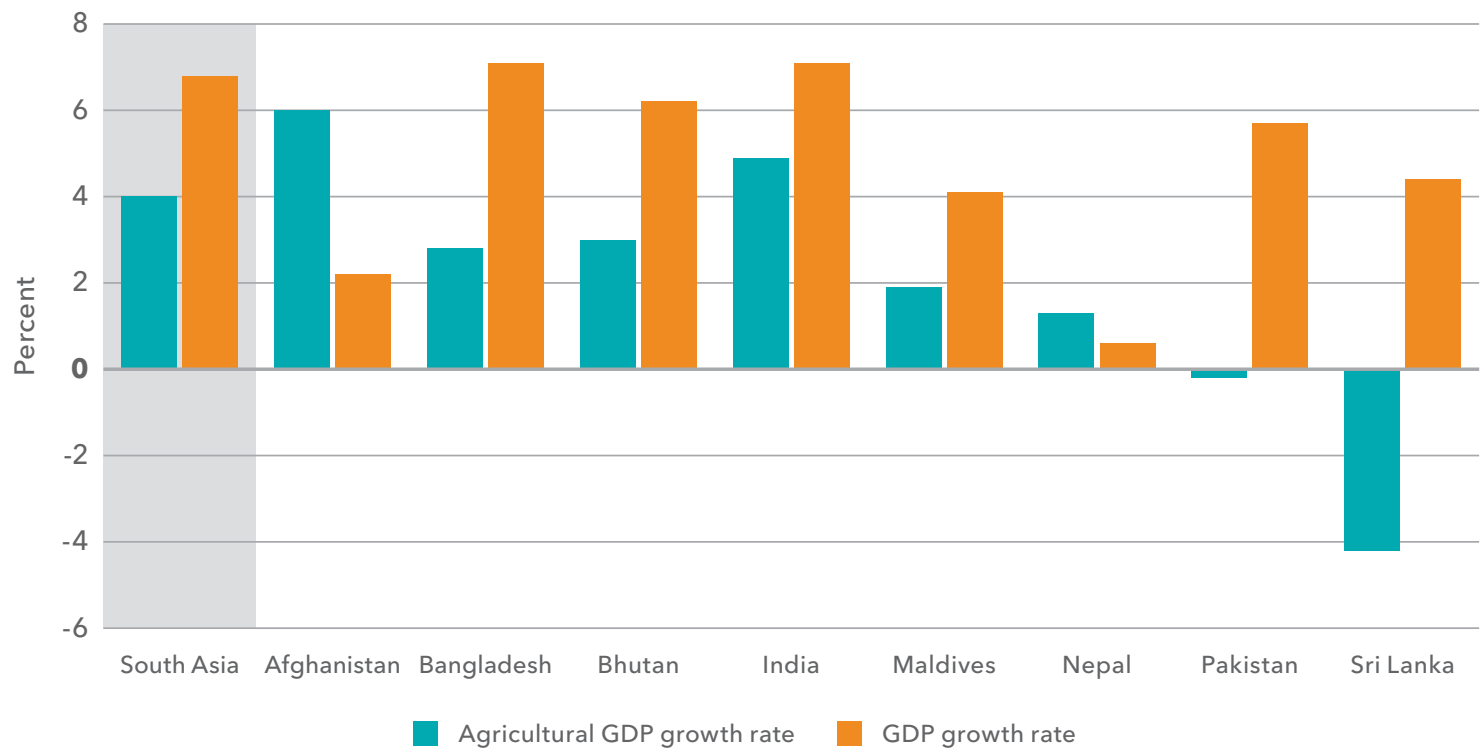

Source: World Bank, World Development Indicators, accessed November 15, 2017, https://data.worldbank.org/.

Note: GDP = gross domestic product. 
which saw a sizable drop in rainy-season food grain production as a result ${ }^{6}$; and below-average rains sharply reduced 2016 cereal production in Pakistan. ${ }^{7}$

\section{INFLATION}

Although consumer price inflation in South Asia slowed from 4.5 percent in 2016 to 4.2 percent in 2017 (Figure 2), ${ }^{8}$ this rate was the second highest among all regions. Moreover, inflation rates varied widely from country to country-from as little as 3.1 percent in the Maldives up to 7.0 percent in Sri Lanka-as did food inflation rates.

Food prices in Afghanistan-particularly of meat, spices, vegetables, and sugar-rose by 4.4 percent in 2016. Average annual inflation in Bangladesh dipped in 2016 and is expected to increase slightly in 2017, given rising nonfood inflation resulting from higher wages and natural gas and electricity prices. In Bhutan, average inflation halved in 2016, but is expected to rise in 2017. Inflation in India remained subdued for a second straight year, averaging 4.5 percent in 2016. In the Maldives, food prices skyrocketed by 70-100 percent when the government lifted subsidies for staple goods, and inflation rose, threatening to reach 3.1 percent in 2017. Inflation in Nepal is expected to drop to 4.5 percent after spiking to 9.9 percent in 2016 due to earthquakes, trade disruptions, and weak agricultural performance. In Pakistan, meanwhile, low global oil and commodities prices, a stable food supply, limited government borrowing, and exchange rate stability brought consumer inflation down to 2.9 percent in 2016, but this is expected to rise to 4.2 percent in 2017 as a result of rising fuel prices and domestic demand. Likewise, average annual inflation in Sri Lanka moderated to 4.0 percent in 2016, but is expected to reach 7.0 percent in 2017.

\section{GLOBAL FOOD VALUE CHAINS, INVESTMENTS, AND FOOD SYSTEMS}

The emergence of global food value chains has changed the nature of food systems across the world and offers new opportunities for South Asian countries to exploit their regional potential. As populations, incomes, and urbanization are all on the rise, consumers in the region are looking toward international markets to satisfy their food demand. South Asia's participation in the global food export market has also expanded. At the same time, the region is one of the least integrated internally: intraregional trade accounts for only 5 percent of South Asia's total trade, whereas it accounts for 25 percent in Southeast Asia. Similarly, intraregional investment makes up less than 1 percent of overall investment. ${ }^{9}$

While foreign direct investment (FDI) decreased globally in 2016, South Asia saw an increase of roughly US $\$ 13$ billion. $^{10}$ In 2017, India alone attracted

FIGURE 2 Year-on-year inflation in South Asia

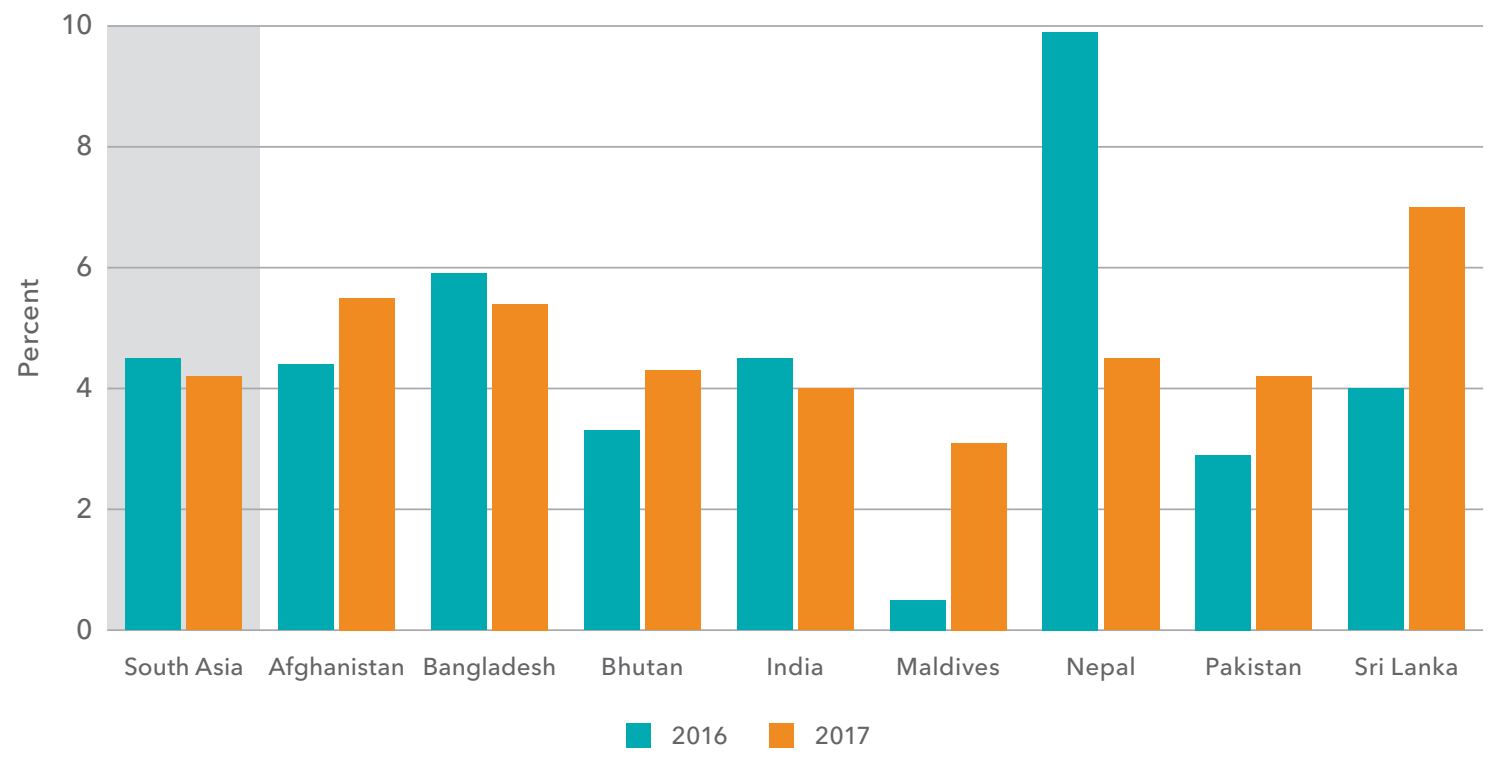

Source: Asian Development Bank, 2017, accessed on November 23, 2017, https://data.adb.org/. 
US $\$ 60$ billion in FDI, as investors gained confidence in India's recent efforts to improve the ease of doing business and reforms in FDI norms. The share of agriculture in total FDI inflow is low, however, accounting for just 3 percent in India and 1.8 percent in Bangladesh.

\section{IMPROVING FOOD AND NUTRITION SECURITY}

Poverty and malnutrition continue to vex South Asia. In 2016, two of every five stunted children in the world lived in the region, and more than 15 percent of children under five in South Asia were wasted. The region's stunting level (38 percent) is just above that of Africa south of the Sahara (37 percent) and more than three times higher than those of East Asia and the Pacific (12 percent) and Latin America (11 percent). ${ }^{11}$

Governments are working to address these challenges. Bangladesh has achieved one of the fastest and most prolonged reductions in child stunting in the world. The country belongs to the global Scaling Up Nutrition (SUN) Movement and participated in the Nutrition for Growth Summit and in Compact2025, enacted a National Nutrition Policy, and planned a nutrition-focused health program. As of 2016, social protection programs covered 28 percent of households and accounted for around 12 percent of public spending (2.2 percent of GDP). ${ }^{12}$ With its National Social Security Strategy, Bangladesh is widening the scope of social protection to include employment policies and social insurance. ${ }^{13}$ Through the Agriculture, Nutrition, and Gender Linkages (ANGeL) research project, the country aims to identify actions and investments in agriculture that will help improve nutrition and empower women. ${ }^{14}$

India, home to roughly 70 percent of South Asia's poor, is implementing numerous nutrition-specific and nutrition-sensitive programs to address the intermediate and underlying causes of undernutrition, including Integrated Child Development Services, the National Rural Health Mission, the Mid-Day Meals Scheme, the National Food Security Mission, and the Mahatma Gandhi National Rural Employment Guarantee Scheme. ${ }^{15}$ Still, high levels of maternal and child undernutrition persist. In September 2017, India unveiled its National Nutrition Strategy, which provides a framework for achieving an "India free from malnutrition," linked to a "clean India" and "healthy India." In December 2017, India launched the National Nutrition Mission with a three-year budget of about US $\$ 1.4$ billion to reduce the prevalence of stunting, undernutrition, anemia, and low-birthweight babies.

Nepal, whose 2015 Constitution enshrined the fundamental right to food, recorded the world's fastest reduction in child stunting in 2016 (from 56.0 percent in 2001 to 35.8 percent). ${ }^{16}$ Nepal belongs to the SUN Movement and is implementing an ambitious multisectoral nutrition program. Pakistan is also a member of the SUN Movement and various associated networks designed to improve nutrition. In May 2016, the Pakistan SUN Movement Secretariat launched a SUN Academia and Research Network. Pakistan's provinces have taken several steps to improve their food and nutrition status since the devolution of power in 2010 and, with support from UNICEF and other partners, developed a multisectoral strategy to help reduce malnutrition.

In Afghanistan, widespread internal displacement and an influx of returnees and refugees continued to hamper access to health and nutrition services in 2016 and $2017 .^{17}$ The government is aiming to reduce child stunting from 41 to 35 percent by 2020 . Afghanistan committed to joining the SUN Movement in 2017. Sri Lanka, in contrast, focused on poverty reduction in 2017 and launched a plan to achieve UN Sustainable Development Goal 2-"to end hunger, achieve food security and improved nutrition, and promote sustainable agriculture" by $2030 .^{18}$ Sri Lanka has been a SUN member since 2012.

\section{REFORMS IN PUBLIC FOOD DISTRIBUTION SYSTEMS}

Poor governance of food distribution is often cited as a barrier to food and nutrition security in South Asia, though most countries in the region have begun taking steps to address this problem. For instance, India is implementing ongoing reforms to its Public Distribution System, including end-to-end automation, digitization, linking identity (Aadhar) cards to ration cards, and installation of electronic points of sale. ${ }^{19}$ Bangladesh is revamping its Public Food Distribution System, instituting a nationwide electronic system for monitoring public food grain stocks, ${ }^{20}$ and implementing the World Bank-financed Modern Food Storage Facilities Project, which will construct eight modern steel grain-storage silos for 
rice and wheat and 500,000 silos for households in disaster-prone areas. Sri Lanka is emphasizing public-private partnership approaches to creating efficient and stable supply chains, developing a national strategic food reserve to guarantee buffer stocks of essential commodities to stabilize prices. Pakistan launched initiatives to improve quality and standards in its food distribution system.

\section{PROMOTING AGRICULTURAL GROWTH}

In 2016-2017, farming in South Asia received increased investments and renewed attention as a result of new programs and policies aimed at boosting productivity through promoting sustainable, diversified, and climate-smart agriculture. Nepal has increased its agricultural budget by about 42 percent over the last two years, and confirmed its commitment to modernize agriculture and achieve self-sufficiency in staple crops, fruits, and vegetables, although this can be a difficult policy to sustain fiscally. ${ }^{21}$ This effort entails facilitating smallholders' access to markets; ensuring that fertilizer, seed, irrigation, and technology are readily available to them; and improving their access to loans and insurance.

Bangladesh is working to increase production of diverse, nutritive, and high-value crops by promoting the use of agricultural technology through policy reforms, regulations, and incentives. Moreover, the country's efforts to liberalize input markets resulted in a greater supply of improved seeds and fertilizers as well as a burgeoning number of food markets and marketplaces where rural women can sell farm products. ${ }^{22}$ Given India's renewed pledge to double farmers' incomes by 2022, the government launched numerous agricultural initiatives in 2017, including increased credit limits for farmers, the creation of long-term and micro-irrigation funds, and a 60-day interest waiver on agricultural credit. The interest waiver may cause market distortions and may be financially unsustainable. India's government also began to remove structural barriers to agricultural development, in part through a series of legislative reforms, and introduced a new program to support start-ups. ${ }^{23}$ The government aims to facilitate a tripling of the capacity of the country's food processing sector and investment in "mega food parks"-networks of collection centers and primary processing centers designed to increase processing of perishable foods. Finally, a major 2017 tax reform will likely constrict the supply of agricultural inputs in the short term due to price adjustments, but should ultimately lower the price of inputs such as fertilizer and machinery. ${ }^{24}$

Pakistan focused on improving productivity of major crops, diverting scarce natural resources toward production of other high-value crops (such as olives and pistachios), and cultivating pulses and oilseeds for import substitution. In addition, several key pieces of seed legislation were passed in the last two years, and some regional-federal efforts are underway to facilitate farming via fertilizer subsidies and interest-free loans. Subsidies run the risk of promoting overuse of fertilizers, with potential negative environmental consequences, and may not be financially sustainable; interest-free loans run the risk of causing market distortions. The Maldives are developing the linkages between agriculture and tourism and raising agricultural productivity through the adoption of climate-smart agriculture. Sri Lanka continues to aim for self-sufficiency in five major food crops through its National Food Program, despite the potential downside of self-sufficiency strategies, and in 2017 the country strengthened its eco-certification program, improved degraded soil, granted income-tax concessions on backward integration activities in agriculture, introduced various subsidies for agribusinesses and fisheries as well as weather index insurance, and established dairy development zones.

\section{CHALLENGES AND OPPORTUNITIES}

Food systems in South Asia are at a crossroads. Climate change is the most pressing issue facing the region, given its implications for the food security of already vulnerable populations. Increasing climatic variability, extreme weather events, and rising temperatures pose new challenges to ensuring food and nutrition security in the region. Global food value chains and robust economic prospects offer untapped potential for prosperity in the region. Equally important are efforts to increase efficiencies, reduce postharvest losses, and develop the agroprocessing sector. Better intraregional linkages and increased intraregional trade will also help the region to grow. In 2018, South Asian countries are expected to reform their agriculture sectors, increase openness to trade, strengthen linkages with global food value chains, and take steps to adapt to climate change and weather uncertainties. 


\section{East and Southeast Asia}

\section{Progress Continues, Challenges Grow}

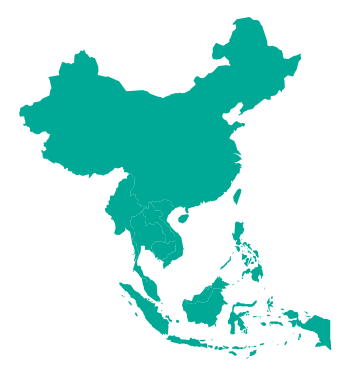

\section{KEVIN CHEN, PETER TIMMER, DAVID DAWE, AND ZIMEIYI WANG}

Kevin Chen is a senior research fellow and head of the East and Central Asia Office, International Food Policy Research Institute (IFPRI), Beijing, China. Peter Timmer is professor emeritus, Harvard University, Cambridge, and a nonresident fellow, Center for Global Development, Washington, DC, USA. David Dawe is a senior economist and regional strategy and policy advisor, Food and Agriculture Organization of the United Nations, Bangkok, Thailand. Zimeiyi Wang is a research assistant, East and Central Asia Office, IFPRI, Beijing, China.

The East and Southeast Asian economies saw strong growth in consumption and investment in 2017. Economic growth in China and the Association of Southeast Asian Nations (ASEAN) is expected to reach 6.8 percent and 5.1 percent for the year, respectively. ${ }^{1}$ Despite this favorable position, food insecurity and malnutrition remain a concern in a number of countries in the region. The 2017 Global Hunger Index reveals that six countries fall into the "serious" category, namely, Cambodia, Indonesia, Lao PDR, Myanmar, the Philippines, and Timor-Leste, while obesity is increasing rapidly throughout the region (albeit from a low base). ${ }^{2}$ To link the region's strong macroeconomic performance with continuing reductions in poverty and malnutrition, broad reforms are likely to be necessary to (1) improve productivity and sustainability in the agriculture and rural sectors, (2) promote and embrace regional integration, and (3) kick economic growth into higher gear.

\section{REGIONAL TRADE DYNAMICS}

China's imports of major agricultural products continued to increase rapidly, creating more opportunities for ASEAN's key agricultural exports. These opportunities are mainly driven by cost differentials and rising demand. China now has the world's largest middle class, with diversified and higher-quality diets. Strong growth in Chinese demand led to a surge in palm oil exports from Malaysia and Indonesia, and rice exports from
Cambodia, Thailand, and Viet Nam. Myanmar also has significant agricultural trade with China. ${ }^{3}$ Benefiting from China's growing appetite, Viet Nam, Thailand, and the Philippines are exporting more tropical fruits, and rising demand has the potential to drive an increase in the export price of some luxury fruits, such as durian, in international markets. ${ }^{4}$ Many regional exporters are seeking ways to penetrate global markets for higher-quality and higher-value products.

Demand for corn and soybean imports is growing in several countries as a result of the shift in domestic demand and trade policies. For example, in Viet Nam, higher incomes, a growing urban population, and a shift to more protein-rich diets combined to boost the country's meat and dairy production, with a corresponding need for animal feed. Viet Nam also needs to feed its rapidly expanding fish and shrimp export sectors. The fast-growing feed industrywhich relies heavily on imported feed ingredients due to inadequate domestic production and low quality-contributed to a surge in soybean and corn imports in $2017 .^{5}$

Facing the same problem, Indonesia imposed tighter rules on imported feed ingredients and is trying to promote domestic production. Indonesia's corn imports declined because of the government's push for corn self-sufficiency and the government may actually prohibit corn imports before the end of 2017 to increase corn prices and give Indonesian farmers an incentive to increase productivity. ${ }^{6}$ Given that feed is the major cost component in poultry 
production, these policies will raise the domestic price of chicken and make it more difficult for the poor to afford this high-quality protein.

\section{STRUCTURAL TRANSFORMATION}

Connecting rural areas to the economic growth process and helping the poor to enter pathways out of poverty requires a successful structural and agricultural transformation. Japan, the Republic of Korea, and Malaysia are well advanced in this transition, with agriculture playing a small role in their economies. Cambodia, Lao PDR, and Myanmar remain at the early stage, where agriculture dominates the economy. China, Indonesia, the Philippines, and Thailand are well into the transition.

Thailand is the largest food exporter in ASEAN, and farm policies will be a crucial element of Thailand's development strategy over the next two decades. Policies designed to upgrade productivity in the farm sector and make the country one of the world's "food super powers" are being prioritized."

China is focusing on reforming its domestic agricultural policies to address the coexistence of excess demand for some high-quality agricultural products and excess supply of key low-quality agricultural products. China also pledged to pursue a rural vitalization strategy, prioritizing the development of agriculture and rural areas in the coming years. ${ }^{8}$ In Viet Nam, the government's agricultural restructuring plan aims to reach 3 percent annual agricultural growth and increase both average labor productivity and the average income of farmers. The government is also implementing a national target program to build a "new countryside" through regional comparative advantage and local specialized products, especially in disaster-prone areas. ${ }^{9}$

Changing land tenure patterns are closely related to agricultural development and the broader process of structural transformation. In much of the region, the transition to larger farm sizes has been very slow, and land fragmentation remains a major obstacle to long-term agricultural investment. However, policy makers are designing land consolidation policies for larger-scale production and economies of scale. China has cleared the way for private investment in large-scale farming. This accelerates a trend toward agricultural capitalism by using "land management rights," which allow a village to collectively transfer its land to a corporation in return for a guaranteed revenue stream. Policies to encourage the lease of land-use rights are also in play in Viet Nam. The country is promoting the establishment of an agricultural land bank that will create a mechanism for mobilizing funds for agricultural development and high-tech production on a large scale. ${ }^{10}$ In Thailand, 800 farm cooperatives nationwide will be tasked by the Thai government with advancing large farms that benefit from economies of scale and greater bargaining power when dealing with middlemen. ${ }^{11}$

\section{BOOMING E-COMMERCE}

With Southeast Asia's skyrocketing internet connectivity and middle-class spending power, e-commerce giants are investing heavily in the region. These investments include the acquisition of Southeast Asian e-commerce platforms by leading companies from China and the United States. ${ }^{12}$ That said, the full potential of these innovations is still unknown. E-commerce could substantially improve the efficiency of agricultural supply chains and strengthen smallholders' access to critical inputs and urban markets. Already, Chinese e-grocery supply chains are using drones to deliver packages throughout rural areas and are setting up fully automated sorting centers. ${ }^{13}$ Online platforms can shorten the value chain by eliminating many middlemen, whose participation drives up prices for consumers and reduces farmers' profit margins.

E-commerce enjoys policy support across the region. China incorporates e-commerce development into its Internet Plus modern agriculture strategy. The Indonesian government is seeking to bring innovation and digital transformation to the largely undigitized agriculture sector. There is also a trend toward simplifying procedures for cross-border e-commerce. Malaysia launched the world's first Digital Free Trade Zone, while the Chinese government continues to provide preferential treatment to overseas goods purchased online and distributed through bonded warehouses. ${ }^{14}$

\section{BUILDING CLIMATE RESILIENCE}

As agricultural production in Southeast Asia is recovering from recent El Niño impacts, promoting resilience and adaptation to climate change remains at 
the top of the agenda. ${ }^{15}$ ASEAN is taking a common stance on this issue, and members are sharing experiences with climate adaptation through regional climate information systems and resilience networks. ${ }^{16}$

Smart farming is the movement of the moment. It represents the application of modern information and communication technologies in agriculture, leading to more precise and sustainable approaches. Countries across the region are designing national strategies to upgrade farming with technology and innovative farming methods that can boost farmers' profits and their ability to adapt to climate change. Thailand is formulating a 20-year national reform program to strengthen farmers' flexibility and diversify agricultural products, with the twin goals of helping farmers escape from poverty and farm sustainably. The Philippine government has tested the use of drones to identify where agricultural land is most vulnerable to natural disasters, and will use the information collected to adapt agricultural plans and better prepare for disasters. Myanmar began promoting climate-smart villages to support community-based adaptation programming. Indonesian farmers, with support from the Food and Agriculture Organization of the United Nations, are using conservation agriculture to make their production more secure. Conservation agriculture includes techniques that minimize soil disturbances and help farming systems weather climate change. ${ }^{17}$

Agricultural genetic resources can be victims of climate change, but they are also of fundamental importance for both climate change adaptation and mitigation. Lao PDR is planning to set up a gene bank for agro-biodiversity protection, primarily to protect its more than 15,000 varieties of rice. A multicountry seed policy agreement was signed by South and Southeast Asian countries to speed up the development and distribution of climate-resilient rice varieties and help vulnerable farmers achieve sustainable production. ${ }^{18}$

\section{REGIONAL INTEGRATION AND THE WAY FORWARD}

Despite rising protectionism around the world, Asian countries are pursuing deeper regional integration. Regional trade is being promoted through a set of plans and mechanisms that outline ASEAN's commitment to regional connectivity through (1) the enhancement of infrastructure, (2) seamless logistics, (3) an improved regulatory environment, (4) digital innovation, and (5) increased labor mobility. ${ }^{19} \mathrm{~A}$ wider bloc is being formed at the same time: the Regional Comprehensive Economic Partnership, a free trade agreement between ten ASEAN members and their six trade partners-Australia, China, India, Japan, New Zealand, and the Republic of Koreawill finalize an agreement at the end of 2018, offering a framework aimed at reducing trade barriers and ensuring improved market access for goods and services. China's Belt and Road Initiative is also welcomed, since it fits with the integration and infrastructure needs of ASEAN. ${ }^{20}$

In contrast to the trend toward integration, major rice importers, including China, Indonesia, Malaysia, and the Philippines, have historically placed great emphasis on self-sufficiency objectives, although such policies tend to cause supply shortages, drive up domestic rice prices, and exclude vulnerable households from the benefits of economic growth. ${ }^{21}$ High rice prices force the poor to spend a large share of their limited budget on rice, compromising their ability to purchase other, more nutritious foods, such as eggs and meat. ${ }^{22}$ Indeed, the Philippines and Indonesia have high child stunting rates for their levels of income (Figure 1), probably caused in part by high rice prices. Lao PDR and Timor-Leste also have high stunting rates and relatively high rice prices. Lowering domestic rice prices would promote more inclusive growth and improve nutrition outcomes.

Looking toward 2018, deeper regional and global market integration, as well as equitable distribution of gains from a broader market, remain a high priority in the region. The Regional Comprehensive Economic Partnership and the Belt and Road Initiative are highly compatible with ASEAN's development strategy and are viewed as important instruments to facilitate trade, economic integration, and market access.

For individual countries, broader trade facilitation measures are needed to take advantage of new market opportunities made possible by free trade agreements. Harmonization of standards and regulations, as well as inspection, certification, and accreditation procedures, are central to fostering market access.

While an integrated market shows great promise, it will be highly competitive. To benefit from opportunities associated with integration, all countries will need to enhance competitiveness by meeting the demands for higher quantity, quality, and safety of food products. Countries in the Greater Mekong 
FIGURE 1 Child stunting prevalence and GDP per capita, selected countries

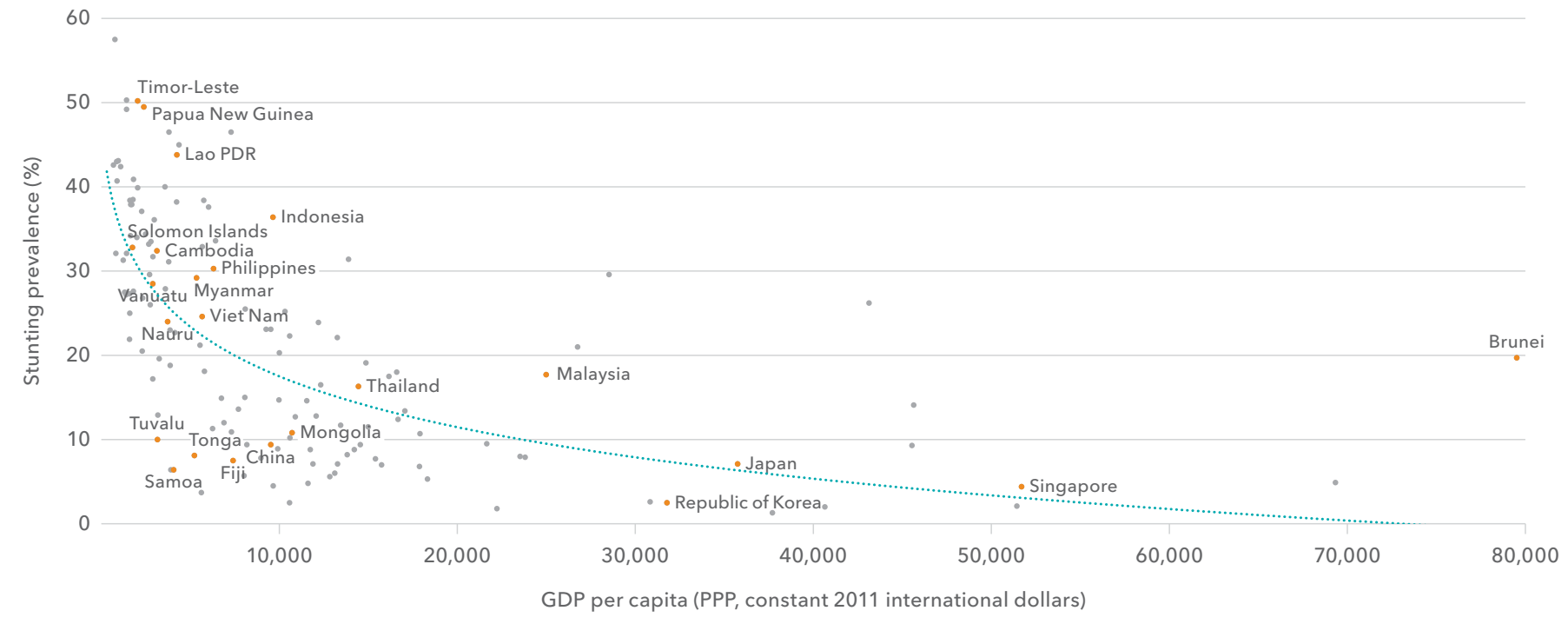

Source: Authors' calculations using data from Development Initiatives, Global Nutrition Report: Nourishing the SDGs (Bristol, UK: 2017).

Note: Data are the most recent available for each country. GDP = gross domestic product.

region (Cambodia, China, Lao PDR, Myanmar, Thailand, and Viet Nam) have already endorsed a five-year strategy and action plan to build a regionwide food safety system that features mutually recognized standards, product tracing, and information sharing. Enhanced food safety regulatory systems can improve competitiveness among food producers in both domestic and international markets, and benefit consumers with safer food and better health. ${ }^{23}$
Going forward, emphasis should be placed on enhancing infrastructure investments, upgrading agricultural value chains (and regulating them to ensure food safety), as well as enhancing farm management systems for higher productivity and reduced ecosystem damage. In the same vein, the region's governments should also incentivize the public and private sectors to promote agricultural research and development. 


\title{
Latin America and the Caribbean
}

\section{Integration and Growth Advance}

\author{
EUGENIO DÍAZ-BONILLA AND VALERIA PIÑEIRO
}

Eugenio Díaz-Bonilla is head of the Latin America and Caribbean program and Valeria Piñeiro is a senior research coordinator, Markets, Trade, and Institutions Division, International Food Policy Research Institute, Washington, DC, USA.

Agricultural production in Latin America and the Caribbean (LAC), along with other commodities, has always played a central role in the region's integration with the global economy. With an evolving range of export crops, the region's economic performance has been closely tied to trends and cycles in international commodity markets. Through different waves of globalization, the region moved toward greater integration into the global economy only to be followed by periods of de-linking. The last several decades saw increased globalization. ${ }^{1}$ For instance, the overall trade-to-gross domestic product (GDP) ratio-a key measure of openness-moved from about 0.20 in the 1960 s to 0.37 in the 2010s. Despite this strong shift, LAC is not the most open region in the world; East Asia and the Pacific's ratio is now at 0.52 . Foreign direct investment, which was about 0.7 percent of the LAC region's GDP in the 1980s, began to increase in the 1990 s (to about 1.7 percent) and reached 2.5 percent in the current decade. For comparison, the average for all developing and emerging markets is about 1.8 percent.

\section{GLOBAL INTEGRATION}

In terms of flows of people, while LAC was historically a significant recipient of immigrants, during recent decades several countries, particularly in the northern part of the region, became sources of migration, primarily to the United States and Europe. As shown by the levels of remittances from nationals living abroad, measured as a percentage of GDP (average 2010s), the countries benefiting most from remittances are Haiti (22.9 percent), Honduras (16.8 percent), El Salvador (16.4 percent), Jamaica (15.7 percent), Guyana (12.6 percent), Guatemala (10.1 percent), Nicaragua (9.5 percent), and the Dominican Republic (7.4 percent). And although the level of remittances is smaller in Mexico (about 2.0 percent), more than 10 percent of Mexico's domestically born population lives in the United States (including people of Mexican descent could more than double that percentage).

LAC's integration into the world economy was historically driven by ties to Europe and the United States, but is now also influenced by China's growing presence as a trade and investment actor in the region. China is currently the top destination for South American exports and the second destination, after the United States, for all LAC exports. However, the composition of LAC exports to China is heavily tilted toward primary commodities, much more so than the overall composition of LAC exports to the world. LAC is primarily buying manufactured goods from China and running a substantial deficit with that country as a result, which has led to increasing doubt about the benefits for LAC of this structure of trade. ${ }^{2}$

To characterize the increasing integration of the Latin American agriculture sector, we look at the export-orientation ratio and the import-penetration ratio-that is, the value of agricultural exports or imports over the value of agricultural production (Table 1).

The export-orientation ratio has increased consistently since the 1990s for the world as a whole, as well as for Mexico/Central America and South America, but has decreased for the Caribbean. The import-penetration ratio has increased for the world and all regions, with the exception of South America, which has remained stable. This suggests that the world as a whole and Mexico/Central America have become more globalized on both the export and import sides since the 1990s, while the Caribbean has increased its integration only on the 
import side, and South America has become more export-oriented as its import ratio remained steady. LAC's growing presence in world agricultural markets is also evidenced by the fact that net exports (exports minus imports) from the region are now the largest at the global level, surpassing the combined net exports of the United States, Canada, Australia, and New Zealand (Figure 1).

As noted in other sections of this report, a heated debate is taking place about whether globalization is a panacea for ending hunger and malnutrition and reducing poverty or whether it has a negative impact on those and other dimensions of welfare in developing countries. ${ }^{3}$ In the case of LAC, growing integration into the global economy developed in parallel with improvements in poverty and undernutrition indicators; the region as a whole attained several of the Millennium Development Goals in 2015 , including cutting by half both the percentage of underweight children under five and undernourishment in the total population between 1990 and 2015 and also reducing by half the percentage of people with incomes below US $\$ 1.25$ (PPP) per day. ${ }^{4}$ However, these changes have been accompanied by an increase in overnutrition and related noncommunicable diseases, problems that nonetheless coexist with undernutrition in some LAC countries. ${ }^{5}$
TABLE 1 Agricultural export and import ratios

\begin{tabular}{|l|c|c|c|}
\hline & \multicolumn{3}{|c|}{ Export-orientation ratios } \\
& $1990 \mathrm{~s}$ & $2000 \mathrm{~s}$ & $2010 \mathrm{~s}$ \\
\hline Caribbean & 0.63 & 0.56 & 0.56 \\
\hline Mexico/Central America & 0.43 & 0.62 & 0.81 \\
\hline South America & 0.48 & 0.65 & 0.64 \\
\hline World & $\mathbf{0 . 3 7}$ & $\mathbf{0 . 4 2}$ & $\mathbf{0 . 4 3}$ \\
\hline & Import-orientation & ratios \\
\hline Caribbean & 0.78 & 1.28 & 1.57 \\
\hline Mexico/Central America & 0.41 & 0.68 & 0.80 \\
\hline South America & 0.18 & 0.17 & 0.17 \\
\hline World & $\mathbf{0 . 3 9}$ & $\mathbf{0 . 4 4}$ & $\mathbf{0 . 4 4}$ \\
\hline
\end{tabular}

Source: $\mathrm{FAO}$ (Food and Agriculture Organization of the United Nations), FAOSTAT database, accessed December 28, 2017, http://faostat.fao.org/.

\section{RECENT DEVELOPMENTS}

After two difficult years in which $L A C$ economies barely grew (less than 0.1 percent regional GDP growth in 2015) or declined (-1.0 percent growth in 2016), the region was projected to grow at 1.1 percent in 2017 and 2.0 percent in 2018. ${ }^{6}$ Although an improvement, these projected rates remain below the more than 3.0 percent growth projected for the

FIGURE 1 Net trade in agricultural products (million current US\$)

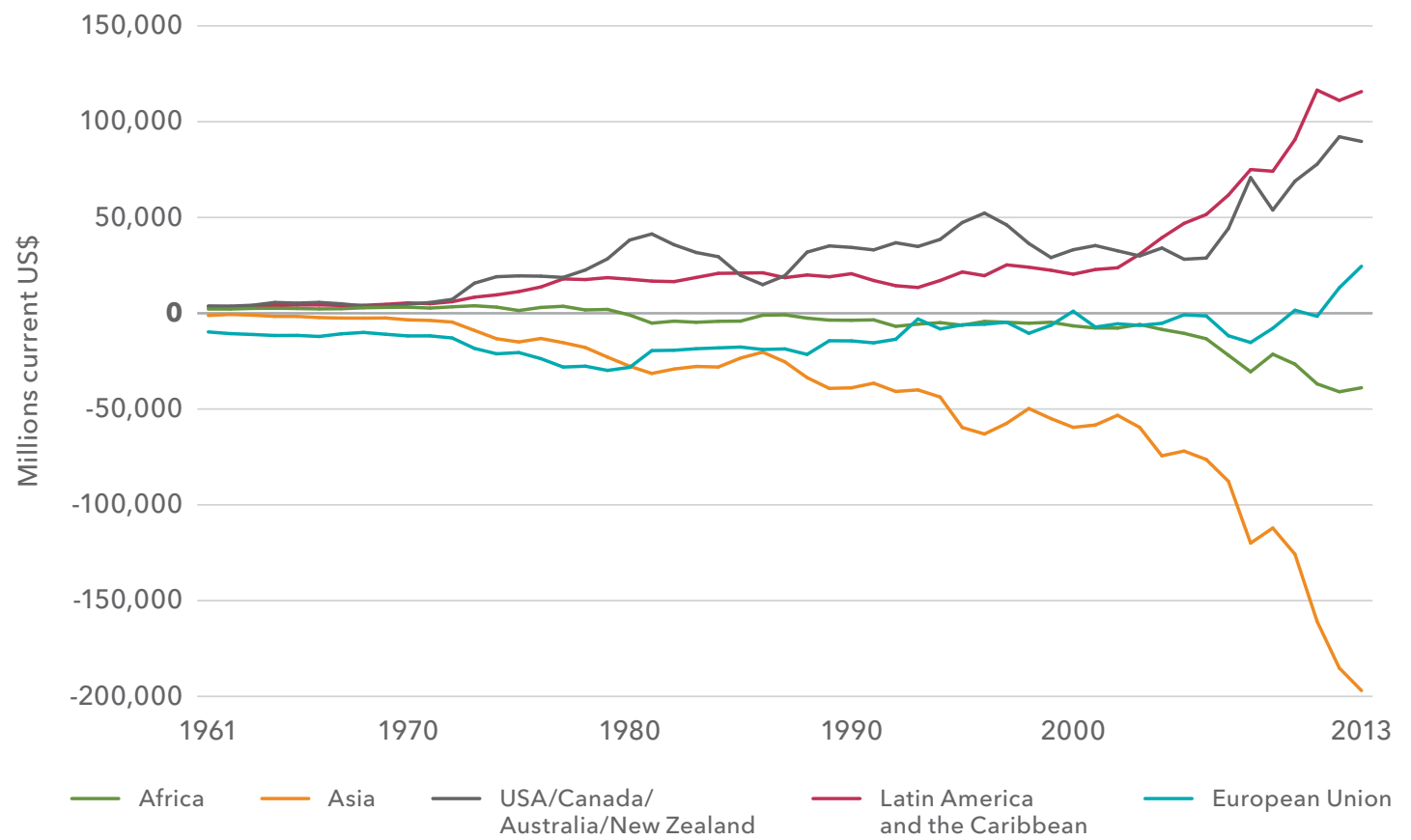

Source: FAO (Food and Agriculture Organization of the United Nations), FAOSTAT database, accessed December 28, 2017, http://faostat.fao.org/. 
world. The slowdown and sluggish recovery have taken a toll in terms of poverty and undernourishment. Recent estimates suggest that undernourishment rates in the region rose from 6.3 percent of the population in 2015 to 6.6 percent in 2016.7

The best economic performers for 2017 are expected to be Bolivia, Costa Rica, the Dominican Republic, Nicaragua, and Panama, all with GDP growth rates of 4.0 percent or higher. In the case of the region's three largest economies, Mexico is projected to have grown at 1.7 percent, Argentina at 2.2 percent, and Brazil at 0.2 percent. For Brazil, which suffered declines of more than 3.0 percent in 2015 and 2016, this represents the beginning of a turnaround. Venezuela continues to be the troubling exception, with per capita GDP projected to have continued shrinking for the fourth consecutive year in 2017 (-7.4 percent), contributing to a cumulative decline of more than 30 percent since 2014 , due to the fall in oil prices, serious macroeconomic imbalances, and political confrontations that have led to hundreds of civilian deaths. Conditions in Venezuela are increasingly worrisome, with acute shortages of food, medicine, and other basic products. International initiatives are starting a mediation process to try to solve the current political conflict-it is hoped that they will succeed in short order.

Policy changes in the United States related to trade and migration are also modifying the context of global integration for LAC countries. The renegotiation of the North American Free Trade Agreement (NAFTA), which has direct implications for Mexico (such as the disruption of the automobile value chain and the potential decline in agricultural imports from the United States), as well as the US decision to withdraw from the Trans-Pacific Partnership agreement that involves Chile, Mexico, and Peru, will have a variety of effects on the competitiveness of different countries and sectors, depending on how the trade talks evolve. The US government also stepped up countervailing and antidumping measures against imports, such as the case of biodiesel with Argentina, while the implementation of market-access measures that were at advanced stages of approval under the previous US administration were delayed (for example, for lemons from Argentina). Beef imports from Brazil were also restricted for a period of time due to concerns about sanitary issues.

Regarding immigration, the US administration announced changes in rules, procedures, and enforcement, potentially leading to higher rates of deportation. These changes are creating uncertainty, particularly for Mexico and several Central American countries, which could experience an increase in deportation of their nationals from the United States and a reduction in remittances, with potentially strong macroeconomic impacts for these countries. ${ }^{8}$ Also, the reinsertion of returned migrants in their own countries could force adjustments in labor markets, fiscal accounts, and business climate conditions.

Finally, the current US administration put on hold the diplomatic opening with Cuba initiated by the previous administration, which may have broad ramifications for hemispheric relations.

In Colombia, since the revised agreement with the largest guerrilla group (FARC, using the Spanish acronym) was approved by the Colombian congress in November 2016, the peace process seems to be moving forward steadily, which offers the prospect of expanded agricultural production in areas previously affected by conflict.

In terms of natural shocks, following the El Niño event in 2015 and 2016 that was associated with various extreme weather events (from droughts in Central America to floods in some Pacific areas), LAC is now coping with a period of heavy rains and hurricanes in the Caribbean. The 2017 hurricane season was particularly active, with eight storms formed and with strengths not seen since 2005. Hurricanes Harvey, Irma, and Maria severely affected several Caribbean islands, with loss of lives and devastation of agricultural and other production and infrastructure.

\section{GROWTH AND UNCERTAINTY}

The world economy improved in 2017, supporting higher commodity prices. Stronger global growth, along with stabilization of the political conditions in key countries such as Brazil, is allowing the region to recover from the difficult economic conditions of 2016, with the exception of Venezuela. Notwithstanding the current economic recovery, the previous downturn negatively affected social indicators, slowing or even reversing the decline in poverty and food insecurity experienced in prior years, while uncertainties about changes in trade, migration, and other policies in the United States act as a damper on prospects for 2018, especially for Mexico and Central America. Countries in LAC should continue to try to combine prudent macroeconomic policies with high-impact investments in human capital, infrastructure, and technology and innovation, ${ }^{9}$ while strengthening democratic governance. 
"At the global, regional, and national levels, data and evidence must remain at the heart of more open, transparent, and inclusive food systems." 